\title{
Dermatome Region
}

National Cancer Institute

\section{Source}

National Cancer Institute. Dermatome Region. NCI Thesaurus. Code C34139.

An area of skin that is supplied by a single spinal nerve. 